\title{
A STUDY OF WORK FROM HOME MOTIVATION AMONG
EMPLOYEES
}

(D) Nur Fadzilah
Muhamad Zamani ${ }^{++}$
(D) Madaha Hanafi @
Mohd Ghani $^{2}$
iD Siti Fatimah
Mohamad Radzi
iD Noor Hanim
Rahmat $^{4}$
(D) Nur Syafiqah
Abdul Kadar
(D) Aina Athirah
Rozman Azram

\author{
1,s Akademi Pengajian Bahasa, Universiti Teknologi MARA Cawangan \\ Johor, Kampus Segamat, Johor Darul Ta'zim, Malaysia. \\ 'Email:nurfadzilahzamani@uitm.edu.my Tel: +6011390746s9 \\ 'Email: sitifatimahradzi@uitm.edu.my.Tel: +60178765141 \\ 'Akademi Pengajian Bahasa, Universiti Teknologi MARA, Cawangan \\ Perak, Kampus Tapah, Perak, Malaysia. \\ Email:madaha@uitm.edu.my Tel: +60139904147 \\ ${ }^{4,6}$ Akademi Pengajian Bahasa, Universiti Teknologi MARA, Shah Alam, \\ Selangor, Malaysia. \\ ${ }^{4}$ Email:noorh76s@uitm.edu.my Tel: +60162155797 \\ 'Email: aathirah@uitm.edu.my Tel: +60182575648 \\ ${ }^{5}$ Akademi Pengajian Bahasa, Universiti Teknologi MARA, Cawangan \\ Selangor, Kampus Dengkil, Dengkil, Selangor, Malaysia. \\ ${ }^{5}$ Email:nursyafiqahkadar@uitm.edu.my Tel:+60132024217
}

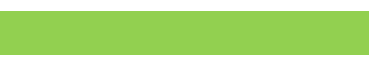

Article History

Received: 31 May 2021 Revised: 25 June 2021

Accepted: 28 July 2021

\section{Keywords}

Work from home

Motivation

Availability

Safety

Meaningfulness

COVID-19.
Published: 23 August 2021

\begin{abstract}
Many sectors are implementing work from home policy as it is one of the effective ways to avoid physical contact among workers and to control the spread of COVID-19. Amidst the stressful pandemic, working from home poses a different kind of stress among both the employers and employees. Numerous studies have found positive and negative consequences of working from home. With or without the pandemic, working from home has become a new way to work. Some industries cannot function well with their employees working from home. Many are finding ways to make work from home a success. This study explores work from home motivation among 53 employees of different industries. The instrument used is a survey. The survey has 4 sections. Section A has 4 items on demographic profile. Section B has 10 items about availability via flexibility. Section $\mathrm{C}$ has 10 items on safety through work-life balance and section D has 10 items on meaningfulness through work performance. Findings reveal interesting motivational influence for employees who work from home.
\end{abstract}

Contribution/ Originality: This paper contributes to the existing literature by offering clear explanations as to what motivate workers to work from home. By measuring and analysing the three motivational factors; availability, safety and meaningfulness of work from home discussed in this paper, employers can strategise systematic plans to ensure a successful practice of work from home among employees.

\section{INTRODUCTION}

\subsection{Background of Study}

The novel Coronavirus (COVID-19), a pandemic attacking people around the globe has challenged the society to start thinking about normalizing new practices, lifestyles and traditions which were once considered fantasy. When the World Health Organization (WHO) declares COVID-19 as a global health crisis, many companies or 
institutions are shut down to adhere to strict policy of social distancing. This has not only impacted people's freedom to socialize or meet physically but also causes most economic sectors to suffer huge revenue loss. As a result, working from home (WFH) is made relevant to be among the possible alternatives to help improve the world's economy hence preventing the virus outbreaks (Bonacini, Gallo, \& Scicchitano, 2021). In fact, the uncertainty about when the pandemic will end has made many to perceive WFH as a 'new norm' to replace the conventional face-to-face working practice. In Malaysia, WFH has gained its importance when the Ministry of Health (MOH) announces Movement Control Order (MCO) in March 2020. The enforcement of MCO is in line with the Prevention and Control of Infectious Disease Act 1988 and the Police Act 1967 where employees, except those working in essential services are not allowed to come to workplaces to avoid making physical meetings (Mat, Edinur, Abdul Razab, \& Safuan, 2020). Even though the MCO has caused a lot of employees to lose their job, the practice of WFH offers people the opportunity to earn money and therefore survive during the pandemic.

Among few other terms which are used interchangeably with WFH include telecommuting, teleworking and remote work. According to Shareena and Shahid (2020) WFH is defined as a concept which requires no workmen to be present at the workplace to perform work duties. It allows people to work remotely in their own premises in which one is not tied to stay during working hours with the employer (Reshma, Aithal, \& Acharya, 2015). Likewise, Grant, Wallace, and Spurgeon (2013) describe WFH as a practice allowing employees to work in flexible workplaces with the help of technology. The use of technology when working from home is crucial in maintaining the success of performing job duties as it acts as a medium that allows people to discuss work-related issues. In addition, Susilo (2020) also reveals that there are many factors which motivate workers to not only enjoy working from home but remain efficient in handling job tasks while being away from the workplace. She elaborates that WFH helps to save one's time and money on commuting besides allowing people to choose their own comfortable workplace. As this happens, they will be more motivated to work and perform well in every task assigned to them. Besides, with proper time management, WFH can also help to improve work-life balance among the employees (Davidescu, Apostu, Paul, \& Casuneanu, 2020).

\subsection{Statement of Problem}

Many sectors are implementing (WFH) policy as it is one of the effective ways to avoid physical contact among workers and to control the spread of COVID-19 (Tantrakarnapa, Bhopdhornangkul, \& Nakhaapakorn, 2020). Jamaludin, Azmir, Mohamad, and Zainal (2020) also agreed that work from home precludes the transmission of the virus as it precludes large presence of workers in the workplace. According to Bawono, Setyadi, and Hamid (2020) having a high work motivation is crucial in producing high performance workers even though they are working from home. Past studies have revealed that working from home increases job satisfaction (Baker, Avery, \& Crawford, 2007; Dwidienawati, Tjahjana, Pradipto, \& Gandasari, 2020; Kröll \& Nüesch, 2019; MacRae \& Sawatzky, 2020; Schall, 2019). As WFH offers flexibility of work, employees can decide their own working time and place that is convenient for them to do their tasks, therefore, it helps them in increasing their performance in work (Abdullah, Rahmati, Zawawi, Khamsah, \& Anuarsham, 2020). In addition, telecommuting saves time for commuting to work as most of the workers travel one hour or more to work (Dwidienawati et al., 2020; Klopotek, 2017). Hence, the workers become less stressed and more relaxed since they do not have to travel to work and face the traffic (Dwidienawati et al., 2020). While working from home, employees can reduce their expenses on travelling, food (eating out for breakfast and lunch) and childcare. It also benefits the employers in operating cost reduction related to renting cost, water, and electricity bills when people work remotely (Heng, San, \& Lee, 2012; Susanne \& Gill, 2003).

However, when people are working from home, positive work experience is not always visible, thus affecting employee's motivation to work. The unrealistic performance expectations and abundance of online meetings along with high work pressure to meet deadlines has caused higher levels of stress among workers when telecommuting. 
Besides, working from home also creates a work-life conflict. Crosbie and Moore (2004) stated that it is difficult to manage work due to domestic responsibilities especially to female workers. During the lockdown due to the pandemic COVID-19, it has created a lot of troubles in coping with work and family together as both parents and children are at home. Due to the role overload, it leads to an increase in daily working hours. Besides, remote working has a high dependency on the internet, weak connection and low speed of internet demotivate the workers to work efficiently (Khandelwal, 2020). Hence, this study intends to investigate what motivates the employees when working from home.

\title{
1.3. Objective and Research Questions
}

This study is done to answer the following questions;

i. How does Availability (flexibility) influence work from home availability?

ii. How does Safety (work-life balance) influence work from home motivation?

iii. How does Meaningfulness (work performance) influence work from home motivation?

\section{LITERATURE REVIEW}

\subsection{Engagement at Work}

Work motivation stems from the workers feeling engagement at work. According to Kahn (1992) employees need three types of engagement at work Figure 1. The first type is (a) availability. This refers to the employees feeling mentally and physically capable to harness their full potential at work. The second type is (b) safety. This refers to the employee feeling safe to show their true self at work without the risk of negative consequences. The third type is (c) meaningfulness. This refers to whether the employee found their work meaningful enough to the organization.

\section{Meaningfulness}

\author{
Safety \\ Availability \\ Figure-1. Engagement at Work. \\ Source: Kahn (1992).
}

\subsection{Past Studies}

Over a period of time, flexibility at the workplace has become a favoured range of research interest and a significant body of studies has been carried out to explore its relationship with workers' motivation and work satisfaction. This is supported by a study conducted by Ahmad, Idris, and Hashim (2013) which investigated the relationship between flexible working hours and employees' motivation. The researchers employed the use of quantitative study, specifically questionnaires, as the research instrument. The independent variable of this research is the flexible working hour whereas staffs' motivation level is the dependent variable. Besides, in data analysis strategy, the researchers used both descriptive and inferential statistics. Meanwhile, to find out the relationship between the two variables, correlation analysis was performed. The findings show that there is a strong relationship between both variables. The results indicated that the implementation of flexible working hours shows a strong relationship to the staffs' motivation in the XYZ Department. The results also confirmed that the implementation of flexible working hours contributed to the staff motivation at XYZ Department. The workers feel comfortable 
with the implementation of staggered working hours compared to the normal working schedule and it allows them to manage their personal matters at home without interrupting working hours.

Apart from that, Davidescu et al. (2020) have examined the link between employees' flexibility and the job satisfaction and job performance among 220 Romanian employees. Besides, the study aims to examine the impact of different types of flexibility such as contractual, functional, working time, and workspace flexibility in increasing the overall level of employees' job satisfaction. This study used a quantitative sociological survey and was participated by workers from 15 to 64 years old. The sampling was probabilistic stage-type stratified. The findings revealed that there is a huge significance among employers' flexibility and their satisfaction and performance. Additionally, the following four types of work flexibility have been analysed: working time flexibility, contractual flexibility, functional flexibility, and workspace flexibility. All four types of flexibilities exhibited a positive effect on job satisfaction and work performance.

A study conducted by Bhumika (2020) investigates the nature of relationship between work-life balance and emotional exhaustion experienced by the employees while working from home during the pandemic COVID-19. The analysis relies on data derived from 180 working professionals in North India who were working from home during the lockdown using PROCESS macro developed for SPSS to test the hypotheses. According to the findings, women experienced more emotional exhaustion than men due to personal life interference in work during the work from home period. There was no gender difference in the relationship between work interference with personal life and emotional exhaustion. It was discovered that participative leadership could aid in reducing work-life conflict. As a result, an employee's emotional exhaustion could be reduced to some extent.

Palumbo, Manna, and Cavallone (2020) studied the implications of home working on work-life balance in educational services. The analysis relies on the secondary data derived from 2046 employees working in the education sector across Europe. A serial mediation analysis was carried out to investigate the direct and indirect effects of working from home on work-life balance. The findings revealed that work-to-life conflict may arise as a result of the blurring of the boundaries between work and everyday life when working from home. Soft Total Quality Management (TQM) such as organisational meaningfulness and work-related well-being mediate the relationship between working from home and work-life conflicts, mitigating the negative effects of working from home on work-life balance. Thus, the design and implementation of working from home arrangements should take soft (TQM) practices into account in order to achieve a sustainable work-life balance.

Palumbo (2020) explores the impact of remote working from home on work-life balance, emphasising the mediating function of work commitment and work-related exhaustion. The study relies on data from the sixth European Working Conditions Survey (EWCS), which included 9877 respondents from across Europe, using a retrospective approach. The results showed that working from home had a negative impact on public servants' work-life balance. Working from home increased work-related exhaustion, which negatively impacted perceived work-life balance. Work commitment, on the other hand, positively mediated the negative impacts of working from home on work-life balance. Overall, though the fact that working from home has been commonly seen as a means of achieving better work-life balance by improved flexibility of working arrangements (Felstead \& Henseke, 2017) the overlapping of work responsibilities and private matters caused by working from home has had disadvantages on workers' ability to establish the distinction between work and life (Crosbie \& Moore, 2004).

The study by Bakan, Buyukbese, Ersahan, and Sezer (2014) was conducted to investigate the impact of job satisfaction on work performance and occupational commitment among academicians in universities. This quantitative study was done on 892 academic staff from Kahramanmaras Sutcu Imam University, Turkey. A structured questionnaire comprising two parts which were demographic features and 54 questions about job satisfaction, work performance and commitment was used as an instrument for data collection. The findings of the study showed that job satisfaction had a positive effect on work performance and occupational commitment. Similarly, the analysis on data collected also revealed a positive impact of occupational commitment on work 
performance. The implication of this study suggested that a comfortable workplace environment helped to create a sense of belonging towards the organization, therefore encouraging the academic staff to be committed and perform well at work. The study by Said, Zaidee, Zahari, Ali, and Salleh (2015) focused on the relationship between three motivational predictors such as individual needs, personal preferences, and work environment on employee job performance. A total of 169 non-academic staff in Universiti Teknologi MARA (UiTM) Terengganu were selected randomly as the respondents to answer a questionnaire consisting of three different sections; (A) demographic questions, (B) dependent variable and (C) independent variables. From this study, it is found that employee motivation had a strong correlation with job performance. In other words, the three motivational predictors had positively and significantly influenced the respondents to perform well at work. The outcome of this study also suggested that in order to keep the employees motivated, it was the management's duty to be heedful of their needs besides maintaining a positive working environment. With a good relationship established between employees and organization, this will not only help in ensuring outstanding work performance among the workers but also reducing employees' turnover.

2.3. Conceptual Framework of the Study

\title{
a.MEANINGFULNESS (Work Performance)
}

\author{
b.SAFETY \\ (Work-Life) \\ c.AVAILABILITY \\ (Flexibility)
}

Figure-2. Conceptual Framework of the Study. Source: Kahn (1992); Abdullah et al. (2020).

Figure 2 presents the conceptual framework of the study. It is rooted from Kahn (1992) and Abdullah et al. (2020). Kahn (1992) engagement at work (a. meaningfulness, b. safety, and c. availability) sets the scaffolds to include the three variables by Abdullah et al. (2020); a.work performance, b. work-life balance, and c-flexibility.

\section{METHODOLOGY}

\subsection{Research Design}

This quantitative study explores the factors that motivate workers who work from home. 53 participants were purposely chosen. The instrument used is a survey adapted from Abdullah et al. (2020). The survey has 4 sections. Section A has 4 items on demographic profile. Section B has 10 items about flexibility. Section C has 10 items on work-life balance and section D has 10 items on work performance. Reliability statistics revealed a Cronbach alpha of .951 (Table 1). Data is collected via google form and analysed using SPSS version 26. Findings are presented in the form of percentages and mean scores.

Table-1. Reliability Statistics for the Study

\begin{tabular}{c|c}
\hline \multicolumn{2}{l|}{ Reliability Statistics } \\
\hline Cronbach's Alpha & Number of Items \\
\hline 0951 & 30 \\
\hline
\end{tabular}




\section{FINDINGS}

\subsection{Findings for Demographic Profile}

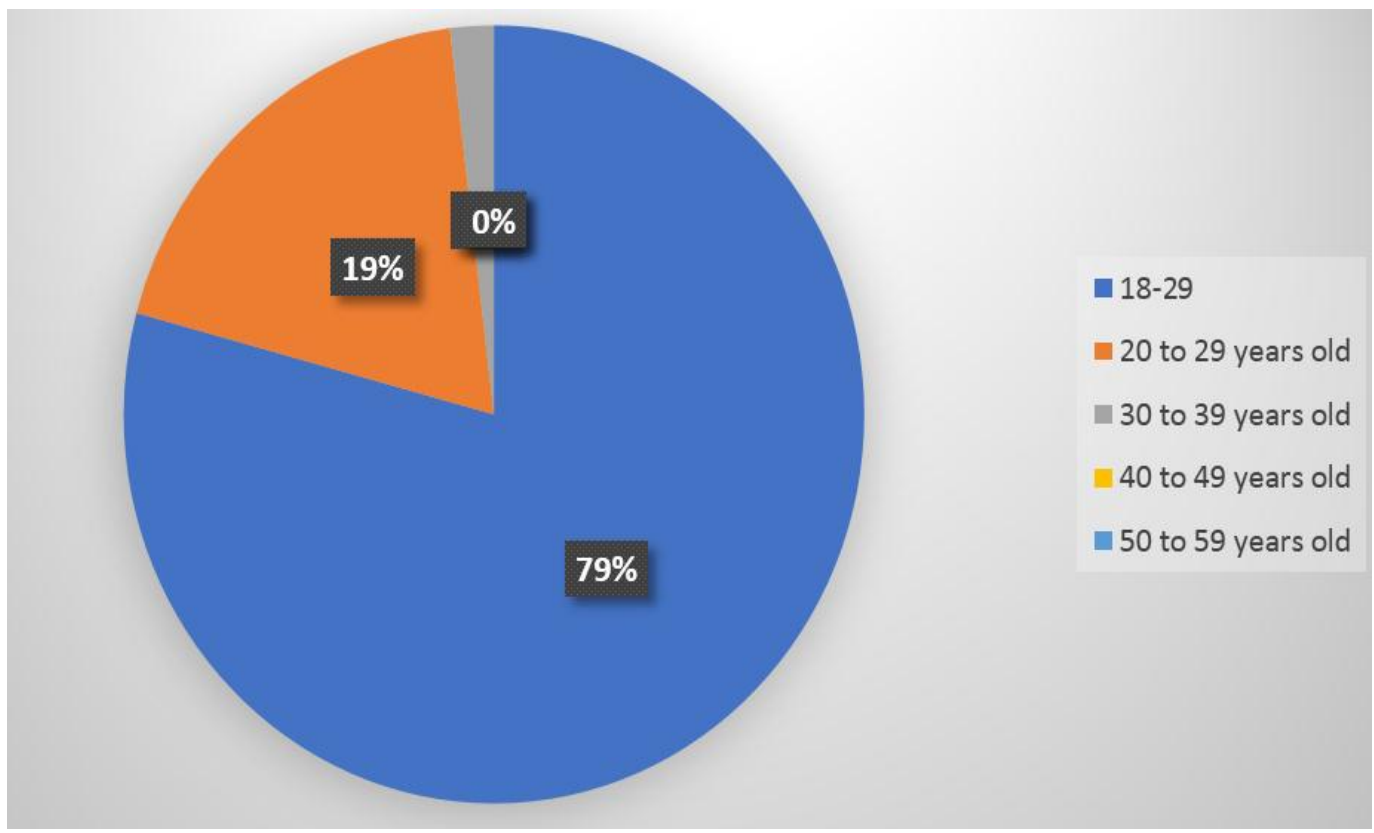

Figure-3. Percentage for Age Group.

The age distribution of the respondents who participated in the study is provided in Figure 3. The largest number of respondents $(79.2 \%)$ were from the age group of $18-29$. This is followed by $18.9 \%$ of respondents between the ages of 20-29 and the least number of respondents were from the age group of 30-39, which was $1.9 \%$ out of the total responses received. Overall, the respondents' ages ranged from 18 to 39 years old, which indicates that those involved in the study were relatively young.

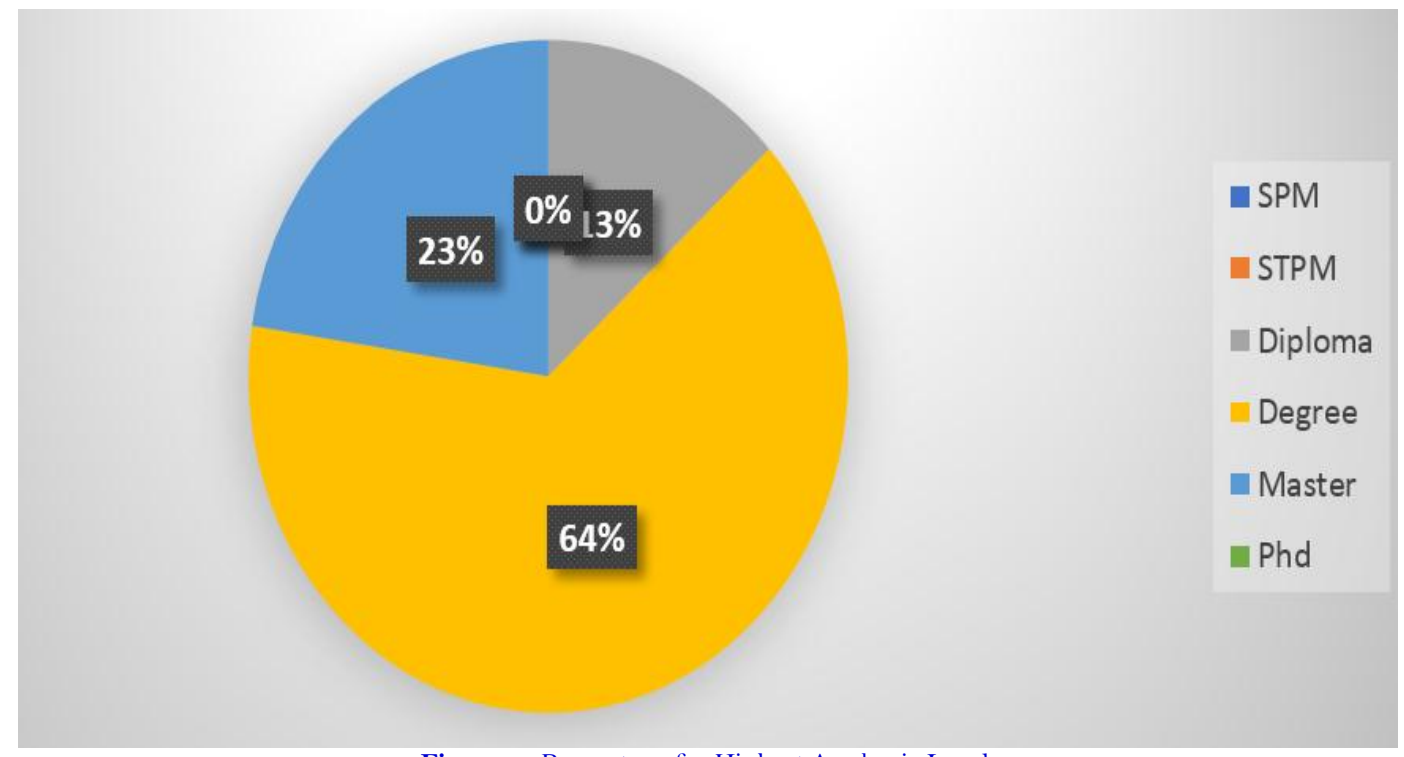

Figure-4. Percentage for Highest Academic Level.

The distribution of the respondents' academic level is shown in Figure 4. Most of the respondents' (64.2\%) highest academic level is Degree. This is followed by Master (22.6\%), and finally, only $13.2 \%$ of the total respondents were recorded with the highest academic level of Diploma. 
Table-2. Percentage for Type of Industry.

\begin{tabular}{l|l|c}
\hline No. & Types of Industry & Percentage \\
\hline 1 & Agricultural, Forestry and Fishing & $0 \%$ \\
\hline 2 & Mining & $0 \%$ \\
\hline 3 & Construction & $1.9 \%$ \\
\hline 4 & Manufacturing & $7.5 \%$ \\
\hline 5 & Transportation \& Public Utilities & $1.9 \%$ \\
\hline 6 & Wholesale Trade & $0 \%$ \\
\hline 7 & Retail Trade & $3.8 \%$ \\
\hline 8 & Finance, Insurance and Real Estate & $7.4 \%$ \\
\hline 9 & Public Services \& Administration & $1.9 \%$ \\
\hline 10 & Health Services & $5.7 \%$ \\
\hline 11 & Food \& Beverage & $1.9 \%$ \\
\hline 12 & Oil \& Gas & $5.7 \%$ \\
\hline 13 & Information Technology & $9.4 \%$ \\
\hline 14 & Education & $50.9 \%$ \\
\hline 15 & Administrative Secretariat & $1.9 \%$ \\
\hline 16 & E Commerce & $1.9 \%$ \\
\hline 17 & Administrative Officers & $1.9 \%$ \\
\hline 18 & Engineering & $1.9 \%$ \\
\hline 19 & Shopping Mall & $1.9 \%$ \\
\hline
\end{tabular}

Table 2 shows the type of industry the respondents belong to. The number of respondents per industry varied considerably. Out of the 52 respondents that were sampled in this study, slightly more than half were from the education industry, which is the highest at $50.9 \%$. The second and third highest industry recorded are Information Technology (9.4\%) and Manufacturing (7.5\%) respectively. In contrast, the lowest number of participants recorded are dispersed among seven different industries which are Public Services and Administration, Food and Beverages, Administrative Secretariat, e-commerce, Administrative Officers, Engineering, and Shopping Mall, which all recorded an equal portion of $1.9 \%$ out of the total respondents recorded. This is followed by the Retail Trade Industry as the second lowest, with only $3.8 \%$ of total participants. Finally, out of the 52 respondents who partook in this study, 5.7\% are from the Health Services Industry. The same number was also recorded for Oil and Gas Industries.

\subsection{Findings for Availability through Flexibility}

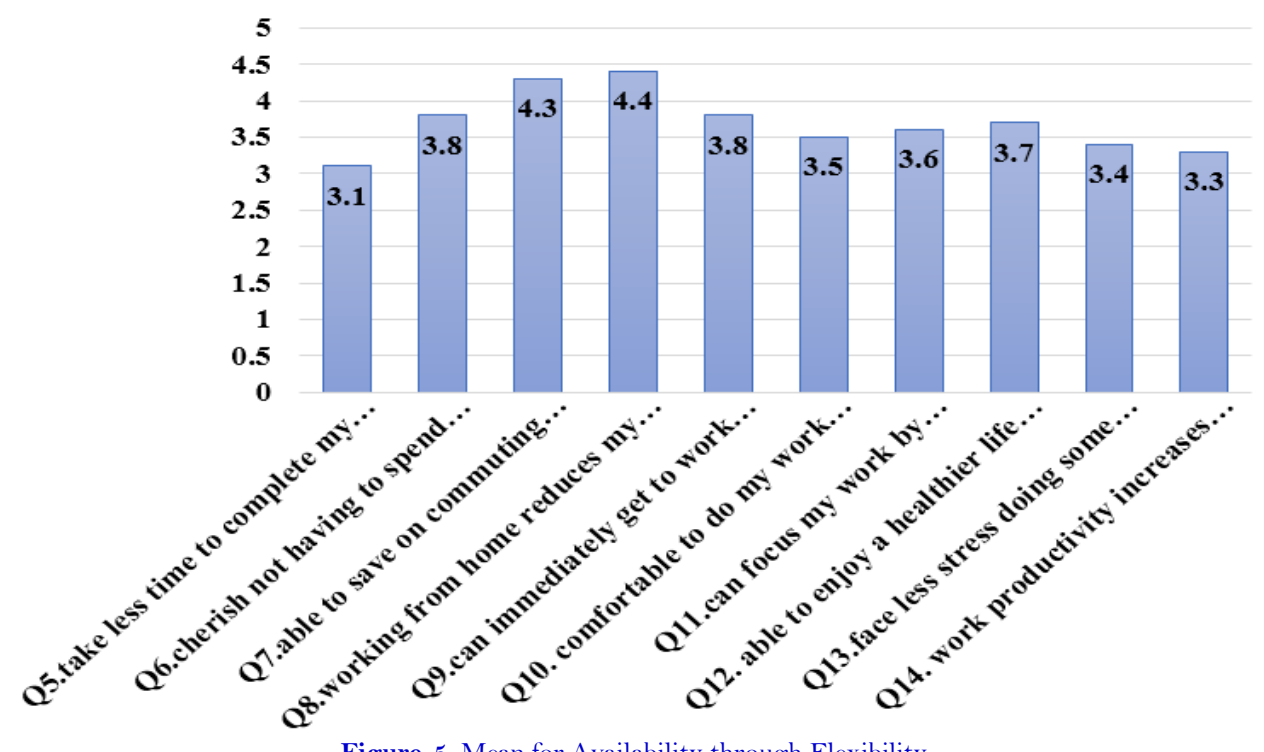

Figure-5. Mean for Availability through Flexibility. 
Figure 5 shows the response of respondents on Flexibility. It can be seen that most of the respondents agree that they are able to save on commuting expenses while working from home as this statement records the highest mean score (4.4). Following that, with only a slight difference, is the second highest mean score (4.3) where most of the respondents agreed that by working from home, it reduces their vehicle maintenance cost. These results tell us that saving money on commuting expenses and maintenance costs are a major motivation factor in influencing the respondents' preference to work from home. Moreover, the third highest mean score (3.8) was recorded for two of the statements given in the survey where respondents agree that they cherish not having to spend time commuting to work on a daily basis and they can immediately get to work upon waking up every day while working from home. Agreement towards these two statements capture time as another work from home motivating factor. Finally, the least important flexibility factor recorded with the lowest mean (3.1) is taking less time to complete their task when they work from home. This shows that respondents do not agree that working from home enables them to spend less time to complete tasks while working.

\subsection{Findings for Safety through Work-life balance}

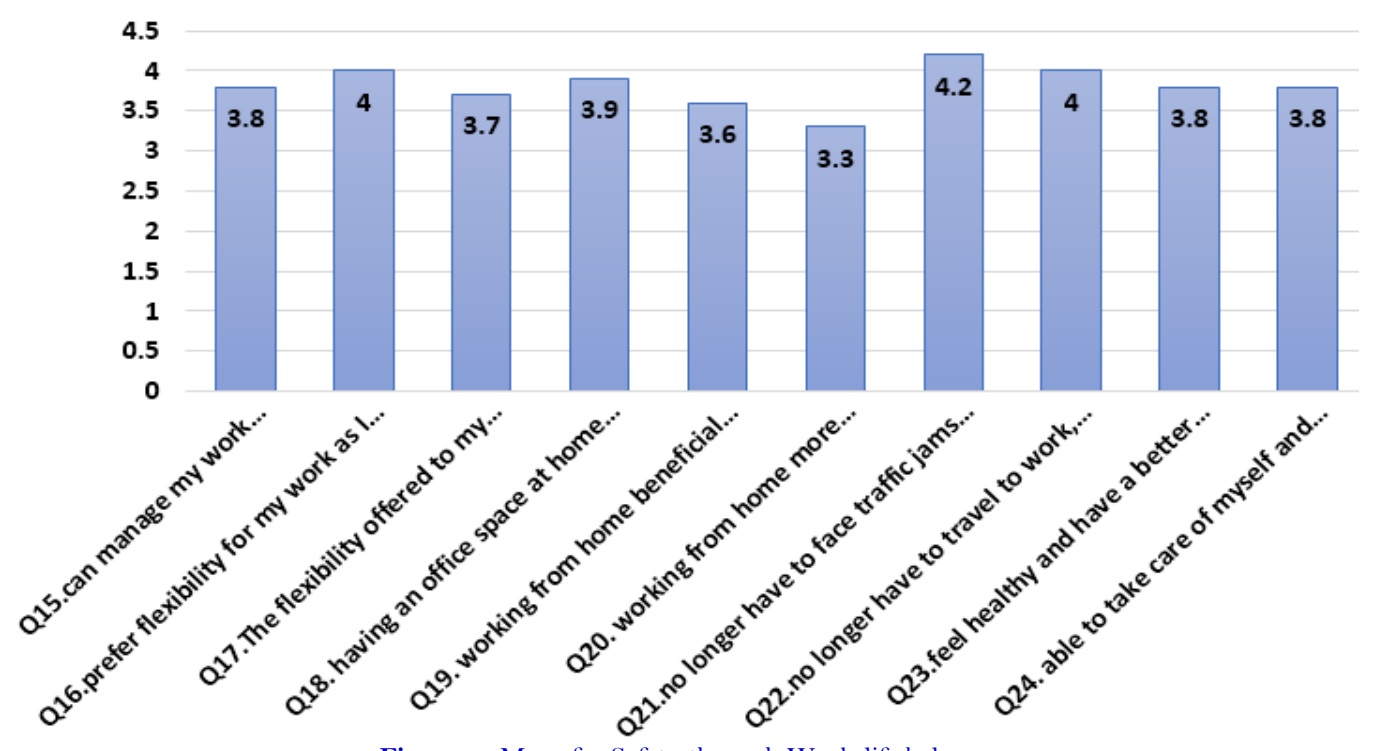

Figure-6. Mean for Safety through Work-life balance.

Figure 6 displays the mean for each of 10 items in section $\mathrm{C}$ of the questionnaire. All items mean more than 3.5 except for item 20. This implies that most respondents agree with the proposed statements. However, they have neutral views regarding the conduciveness of working from home. This means that all respondents could not be decisive in choosing to work at home or at the office despite the highest mean (4.2) recorded for item 21 regarding no traffic jam problem to go for work. All responses portray that work-life balance is more significant when working from home.

\subsection{Findings for Meaningfulness through Work Performance}

Figure 7 indicates the concerns of having a meaningful work performance from home. The highest mean of 3.7 is reflected on both item 26 and 33 namely My employer has high trust in employees working from home and I can detect a fraud email whenever I receive them in my inbox. These two items are intangible experiences therefore the highest mean for both portrays that, employers are convinced with flexibility given to their employees without jeopardizing work performance. The lowest mean of only 2.6 displayed for item 28 in which most employers did not provide ergonomic chairs for employees working home. Thus, this finding shows that employees did not have compelling challenges in accommodating work performance meaningfulness from home. 


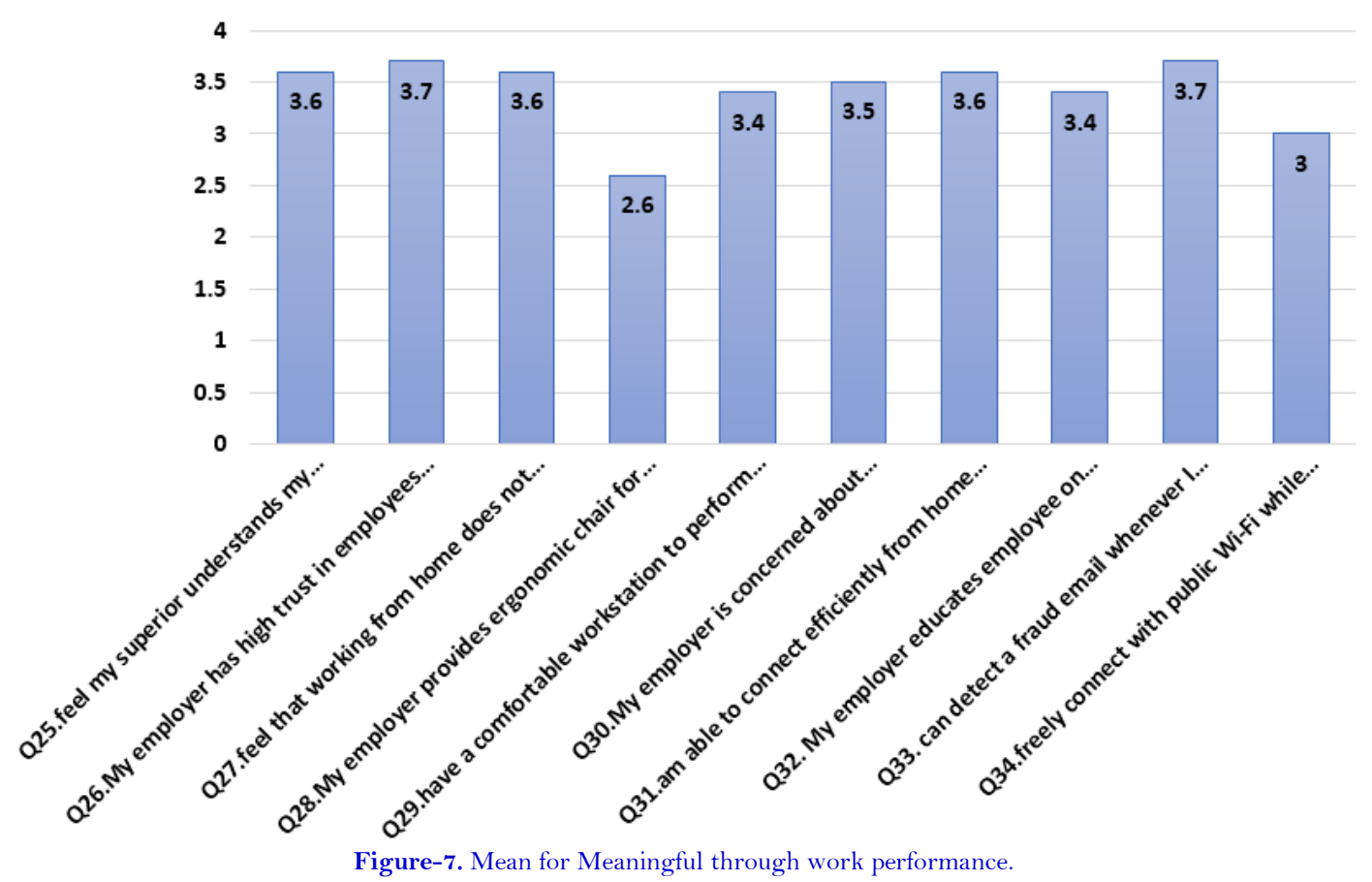

\section{CONCLUSION}

\subsection{Summary of Findings and Discussion}

The findings in the study reveal that one of the positive outcomes from working from home is the workers appreciate the functional flexibility. They liked the fact that they could cut down on travelling to and from work. This is agreed by Davidescu et al. (2020) who presented four types of work flexibility at the workplace: working time flexibility, contractual flexibility, functional flexibility, and workspace flexibility. All four types of flexibilities exhibited a positive effect on job satisfaction and work performance. Respondents felt that they can achieve worklife balance when they are given the freedom and authority to reduce shift focus weightage for work to family's needs and vice versa and still do well in both. This is also agreed by Davidescu et al. (2020) who also agreed that work-life balance gives workers emotional stability so they can perform better at work.

\subsection{Implications and Suggestion for Future Research}

With or without the pandemic, working from home has become a new way to work. Measures should be taken by employers to ensure productivity does not suffer. Measures must be taken by employees to make sure they work with integrity. It is suggested that future researchers explore more factors that influence employees working from home. Future researchers could interview both parties-employers and employees-on their hope and fear about working from home.

Funding: This study received no specific financial support.

Competing Interests: The authors declare that they have no competing interests.

Acknowledgement: All authors contributed equally to the conception and design of the study.

\section{REFERENCES}

Abdullah, N. A. A., Rahmati, N. H., Zawawi, F. Z., Khamsah, M. A. N., \& Anuarsham, A. H. (2020). Coping with post covid-19: Can work from home be a new norm? European Journal of Social Sciences, 5(6), 1-21. Available at: https://doi.org/10.46827/ejsss.v5i6.933.

Ahmad, A. R., Idris, M. T. M., \& Hashim, M. H. (2013). A study of flexible working hours and motivation. Asian Social Science, 9(3), 208-2 15. Available at: https://doi.org/10.5539/ass.v9n3p208. 
Bakan, I., Buyukbese, T., Ersahan, B., \& Sezer, B. (2014). Effects of job satisfaction on job performance and occupational commitment. International Journal of Management \& Information Technology, 9(1), 1472-1480. Available at: http://doi.org/http://dx.doi.org/10.24297/ijmit.v9i1.668.

Baker, E., Avery, G. C., \& Crawford, J. (2007). Satisfaction and perceived productivity when professionals work from home. Research and Practice in Human Resource Management, 15(1), 37-62.

Bawono, I. R., Setyadi, E., \& Hamid, S. A. (2020). Work motivation effect on state civil apparatus performance during WFH with discipline variable. Accrual: Accounting Journal, 11(2), 110-121. Available at: https://doi.org/10.26740/jaj.v11n2.p1 10121.

Bhumika. (2020). Challenges for work-life balance during COVID-19 induced nationwide lockdown: Exploring gender difference in emotional exhaustion in the Indian setting. Gender in Management, 35(7), 705-718. Available at: https://doi.org/10.1108/GM-06-2020-0163.

Bonacini, L., Gallo, G., \& Scicchitano, S. (2021). Working from home and income inequality: Risks of a 'new normal'with COVID-19. Journal of Population Economics, 34(1), 303-360. Available at: https://doi.org/10.1007/s00148-020-008007.

Crosbie, T., \& Moore, J. (2004). Work-life balance and working from home. Social Policy and Society, 3(3), 223-233.

Davidescu, A. A., Apostu, S. A., Paul, A., \& Casuneanu, I. (2020). Work flexibility, job satisfaction, and job performance among Romanian employees - implications for sustainable human resource management. Sustainability, 12(15), 6086. Available at: https://doi.org/10.3390/su12156086.

Dwidienawati, D., Tjahjana, D., Pradipto, Y. D., \& Gandasari, D. (2020). Is your work from home job satisfying? Lesson learned from work from home during COVID-19 outbreak in Indinesia. Journal of Social Sciences, 48(3), 743-752.

Felstead, A., \& Henseke, G. (2017). Assessing the growth of remote working and its consequences for effort, well-being and work-life balance. New Technology, Work and Employment, 32(3), 195-212. Available at: https://doi.org/10.1111/ntwe.12097.

Grant, C. A., Wallace, L. M., \& Spurgeon, P. C. (2013). An exploration of the psychological factors affecting remote e-worker's job effectiveness, well-being and work-life balance. Employee Relations, 35(5), 527-546. Available at: https://doi.org/10.1 108/er-08-2012-0059.

Heng, T. B., San, O. T., \& Lee, L. Y. (2012). The acceptance and effectiveness of telecommuting (work from home) in Malaysia. Asia Pacific Journal of Research in Business Management, 3(3), 1-19.

Jamaludin, S., Azmir, N. A., Mohamad, A. A. F., \& Zainal, N. (2020). COVID-19 exit strategy: Transitioning towards a new normal. Annals of Medicine and Surgery, 59, 165-170. Available at: https://doi.org/10.1016/j.amsu.2020.09.046.

Kahn, W. A. (1992). To be fully there: Psychological presence at work. Human Relations, 45(4), 321-349. Available at: https://doi.org/10.1177/001872679204500402.

Khandelwal, M. (2020). Work from home: Meeting the change in workplace. Research Reinforcement A Peer Reviewed International Refereed Journal, 8(1), 82-89.

Klopotek, M. (2017). The advantages and disadvantages of remote working from the perspective of young employees. Scientific Quarterly "Organization and Management, 4(40), 39-49.

Kröll, C., \& Nüesch, S. (2019). The effects of flexible work practices on employee attitudes: Evidence from a large-scale panel study in Germany. The International Journal of Human Resource Management, 30(9), 1505-1525. Available at: https://doi.org/10.1080/09585192.2017.1289548.

MacRae, I., \& Sawatzky, R. (2020). Remote working: Personality and performance research results. Retrieved from https://static1.squarespace.com/static/5b045109c258b4052b14cdod/t/5e28792a6b8c1a130743bec1/1579710768235/ Remote+Working+Personality+and+Performance+Research+Results.pdf.

Mat, C. N. F., Edinur, H. A., Abdul Razab, M. K. A., \& Safuan, S. (2020). A single mass gathering resulted in massive transmission of COVID-19 infections in Malaysia with further international spread. Journal of Travel Medicine, 27(3), 19. 
Palumbo, R., Manna, R., \& Cavallone, M. (2020). Beware of side effects on quality! Investigating the implications of home working on work-life balance in educational services. TQM Journal, 33(4), 915-929. Available at: https://doi.org/10.1108/TQM-05-2020-0120.

Palumbo, R. (2020). Let me go to the office! An investigation into the side effects of working from home on work-life balance. International Journal of Public Sector Management, 33(6-7), 771-790. Available at: https://doi.org/10.1 108/IJPSM-062020-0150.

Reshma, P., Aithal, P., \& Acharya, S. (2015). An empirical study on Working from Home: A popular e-business model. International Journal of Advance and Innovative Research, 2(2), 12-18. Available at: https:// www.academia.edu/25156478.

Said, N. S. M., Zaidee, A. S. E. A., Zahari, A. S. M., Ali, S. R. O., \& Salleh, S. M. (2015). Relationship between employee motivation and job performance: A study at MARA university of technology (Terengganu). Mediterranean Journal of Social Sciences, 6(4), 632-632. Available at: https://doi.org/10.5901/mjss.2015.v6n4s2p632.

Schall, M. A. (2019). The relationship between remote work and job satisfaction: The mediating roles of perceived autonomy, work-family conflict, and telecommuting intensity. Master's Thesis. San Jose State University.

Shareena, P., \& Shahid, M. (2020). Work from home during covid 19: Employees' perception and experiences. Global Journal For Research Analysis, 9(5), 2277-8160.

Susanne, T., \& Gill, M. (2003). The times and temporalities of home-based telework. Personnel Revierw, 32(4), 438-455. Available at: https://doi.org/10.1108/00483480310477524.

Susilo, D. (2020). Revealing the effect of work-from-home on job performance during the COVID-19 crisis: Empirical evidence from Indonesia. Journal of Contemporary Issues in Business and Government, 26(1), 23-40. Available at: https://doi.org/10.47750/cibg.2020.26.01.002.

Tantrakarnapa, K., Bhopdhornangkul, B., \& Nakhaapakorn, K. (2020). Influencing factors of COVID-19 spreading: A case study of Thailand. Journal of Public Health, 1-7. Available at: https://doi.org/10.1007/s10389-020-01329-5. 